\title{
IMPLEMENTASI METODE TALAQQI DAN MUSYAFAHAH DALAM MENINGKATKAN KEMAMPUAN MEMBACA AL-QUR'AN SISWA DI SD SWASTA SALSA
}

\author{
Muhammad Arsyad Suriansyah \\ Universitas Islam Negeri Sumatera Utara Medan \\ E-mail: arsyadsuriansyah@gmail.com \\ How to Cite:
}

Suriansyah, M. A. (2020). Implementasi Metode Talaqqi dan Musyafahab dalam Meningkatkan Kemampuan Membaca Al-Qur'an Siswa di SD Swasta Salsa. Fitrab: Journal of Islamic Education, 1(2). 216-231.

\section{ARTICLE HISTORY \\ Received :22 November 2020 \\ Revised :02 January 2021 \\ Accepted :29 January 2021 \\ Published :31 January 2021}

\section{KEYWORDS:}

Al-Qur'an, Tahsin, Talaqqi Musyafahah, Tajwid

\section{ABSTRACT}

This study aims to analyze the implementation of talaqqi and musyafahah methods in improving students' reading ability of the AlQur'an at Salsa Percut Sei Tuan Private Elementary School. The method used was Classroom Action Research with two cycle's stages. Each cycle is carried out following the planning, implementation, observation and reflection procedures. Data were collected using observation, interview, test and documentation techniques. The results showed that the students' ability to read Al-Qur'an in pre-action still did not meet the minimum completeness criteria. In cycle 1 the students' ability to read the Al-Qur'an who was able to fulfill the minimum completeness criteria were only 2 students (makharijul buruf), 1 student (sifatul buruf), and 2 students (abkamul buruf), after learning in cycle 2 increased, so that those who were able to fulfill the minimum completeness criteria into 8 students (makharijul buruf), 8 students (sifatul buruf), and 8 (abkamul buruf) students. These results indicate that the learning outcomes score has exceeded the specified minimum completeness criteria. The application of this learning method has also received a good response by students; this can be seen from the enthusiasm and increasing attractiveness of students to learn tajwid.

\begin{tabular}{|c|c|c|}
\hline \multicolumn{3}{|c|}{ RIWAYAT ARTIKEL } \\
\hline Diter & :22 No & 2020 \\
\hline Direvisi & :02 January & 2021 \\
\hline Disetujui & :29 January & 2021 \\
\hline Diterbitka & :31 January & 2021 \\
\hline
\end{tabular}

\section{KATA KUNCI:}

Al-Qur'an, Tahsin, Talaqqi Musyafahah, Tajwid

ABSTRAK
Penelitian ini bertujuan menganalisis implementasi metode talaqqi dan
musyafahah dalam meningkatkan kemampuan membaca Al-Qur'an
siswa di SD Swasta Salsa Percut Sei Tuan. Metode yang digunakan
ialah Penelitian Tindakan Kelas (PTK) dengan tahapan dua siklus.
Setiap siklus terdiri dari empat langkah yakni perencanaan,
pelaksanaan, observasi dan refleksi. Data dikumpulkan dengan
menggunakan teknik observasi, wawancara, tes dan dokumentasi.
Hasil penelitian menunjukkan bahwa kemampuan membaca Al-Qur'an
siswa pada pra tindakan masih belum memenuhi kiteria ketuntasan
minimal. Pada siklus 1 kemampuan membaca Al-Qur'an siswa yang
mampu memenuhi KKM hanya 2 siswa (makharijul buruf), 1 siswa
(sifatul huruf), dan 2 siswa (ahkamul makharijul huruf), setelah
dilaksanakan pembelajaran pada siklus 2 meningkat, sehingga yang
mampu memenuhi KKM menjadi 8 siswa (makharijul huruf), 8 siswa
(sifatul huruf), dan 8 (abkamul huruf) siswa. Hasil ini menunjukkan bahwa
skor hasil belajar tersebut telah melampaui batas KKM yang telah
ditetapkan. Respon dari penerapan metode ini siswa terlihat antusias
dan meningkatnya daya tarik siswa untuk mempelajari tajwid.




\section{PENDAHULUAN}

Kecanggihan teknologi membuat banyak bermunculan inovasi pembelajaran. Tak heran saat ini seorang siswa dapat dengan mudah untuk belajar, bahkan tanpa harus terhalang waktu, tempat, bahkan pendidik sekalipun. Seseorang yang tidak sama sekali mengetahui pun akan dapat dengan mudah untuk belajar bahkan tanpa kehadiran seorang guru. (Hadisi \& Muna, 2015).

Namun kondisi seperti ini tentu memiliki kelebihan dan kelemahan. Kelebihanya tentu mempermudah akses, mempersempit jarak, dan mengefisiensi waktu. Sedangkan kelemahannya tidak adanya komunikasi dan interaksi dua arah, dan evaluasi ketercapaian yang tidak akurat. (Rusadi et al., 2019)

Kelemahan pembelajaran berbasis teknologi sangat dirasakan oleh para guru yang berkecimpung dalam pengajaran AlQur'an. Bagi kalangan dewasa tentu akan dapat dengan mudah untuk belajar tanpa guru dengan berbantuan teknologi pembelajaran. (Lubis et al., 2019). Ringkasnya mereka akan mudah untuk belajar Al-Qur'an melalui internet seperti channel youtube dan lain sebagainya. Akan tetapi bagi anak-anak yang masih terbilang pemula tentu pembelajaran Al-Qur'an tanpa guru akan menyulitkan siwa, dan bahkan dapat dipastikan jika pun bias akan terdapat ketidaksesuaian dengan sebagaimana mestinya.(Lubis et al., 2020)

Pembelajaran Al-Qur'an dengan menggunakan bantuan media pembelajaran ineternet memang terbilang media pembelajaran modern, dan yang mulai banyak dilirik oleh masyrakat modern.
Akan tetapi tidak sepenuhnya pembelajaran modern dapat menyelesaikan semua problem persoalan pembelajaran masa kini. (Sopianudin, 2018).

Pembelajaran membaca Al-Qur'an menyangkut kaidah tajwid yang tidak hanya menuntut pemahaman saja akan tetapi menuntut keterampilan dalam ketepatan lisan dan suara dalam membaca sesuai dengan kaidah tajwid yang ada. Tentu saja dalam hal tuntutan pemahaman dapat saja dilakukan dengan jarak jauh atau dilakukan melalui internet atau dengan kata lain dilakukan satu arah atau secara mandiri oleh siswa tersebut. Namun untuk keterampilan tentu siswa membutuhkan seorang guru atau pun yang ahli di bidangnya untuk melatih, dan menilai perkembangan ketepatan lisan dalam membaca Al-Qur'an sesuai tajwid. Ringkasnya dituntut adanya interaksi atau komunikasi dua arah antara pendidik dengan siswa. (Putra \& Radita, 2020).

Pembelajaran dengan cara ini memang dianggap sebagian kelangan sebagai pembelajaran yang masih kuno dan terkesan tidak modern, akan tetapi pembelajaran seperti ini memang menghendaki metode tatap muka, bahkan akan berbahaya jika dilakukan secara daring ataupun satu arah dengan menggunakan internet. Dikatakan berbahaya karena pembelajaran Al-Qur'an bukanlah kemampuan yang bekalnya hanya untuk satu atau beberapa hari digunakan, akan tetapi bekal keterampilan membaca Al-Qur'an menjadi keterampilan yang akan terus mereka pergunakan sampai akhir hayat seseorang. Sebab seseorang membaca $\mathrm{Al}-$ Qur'an bukan untuk sehari atau beberapa hari saja, akan tetapi untuk selamanya, 
karena membaca terhitung ibadah, dan membacanya merupakan keharusan bagi umat Islam, karena Al-Qur'an merupakan sumber hukum Islam.

Tabsin Al-Qur'an merupakan istilah untuk pembelajaran Al-Qur'an yang menuntut individu untuk tepat membaca sesuai dengan kaidah ilmu tajwid. Pembelajaran tabsin Qur'an merupakan salah satu pembelajaran Al-Qur'an dengan memproyeksikan kaidah ilmu tajwid, dalam hal ini perlunya memilih strategi maupun metode yang tepat untuk mengajarkan kepada peserta didik. Karakteristik memilih metode pembelajaran itu sendiri memiliki keefektifitasannya masing-masing, tentunya harus menyesuaikan situasi dan kondisi dalam penerapannya sehingga mencapai tujuan yang diharapkan.

Pembelajaran tabsin Al-Qur'an pada anak usia dasar menuntut kehadiran siswa dihadapan guru, sebab pada usia tersebut mereka masih tergolong sangat pemula, dan tidak mampu secara mandiri untuk menilai perkembangan belajarnya. Jika pembelajaran dilakukan tanpa guru, seperti yang banyak terjadi saat ini (belajar dari internet) dikhawatirkan tidak sempurna.

Dalam istilah pembelajaran AlQur'an metode pembelajaran yang menuntut tatap muka dan tuntunan langsung dari sang guru disebut dengan metode talaqqi dan musyafabah. Metode ini pada pada dasarnya merupakan metode yang berkonsep pada ajaran yang disampaikan oleh Rasulullah Saw. dalam mempelajari Al-Qur'an. Hal tersebut dapat dilihat melalui sejarah kehidupan Rasulullah Saw. mendapatkan wahyu dari Allah yang pertama kali di Gua
Hira berhadapan secara langsung dengan malaikat Jibril yaitu saat menerima surah al'Alaq ayat 1-5.

Metode ini menawarkan banyak keutamaan terutaman dalam memperbaiki kesalahan-kesalahan membaca Al-Qur'an. Pendidik dapat melihat secara langsung sejauh mana fashih atau tidaknya peserta didik dalam membaca Al-Qur'an. Dengan dilakukakannya metode talaqqi dan musyafahah ini, peserta didik berhadapan secara langsung face to face dan mengikuti apa yang diucapkan pendidik guna memperbaiki kesalahan-kesalahan dari bacaan AlQur'annya. Perbaikan kesalahan tersebut meliputi makharij al-Huruf (tempat keluarnya huruf), shifat al-Huruf (sifat huruf) dan abkam al-Huruf (hukum-hukum huruf)

Metode talaqqi dan musyafahab juga memungkinkan guru untuk memeberikan hubungan psikologis yang membuat siswa merasa nyaman ketika sedang mempelajari Al-Qur'an. Siswa yang memiliki hambatan baik dari sisi pemahaman dan psikologis akan dapat langsung ditangani oleh guru. Hal ini lah yang tidak dapat dilakukan oleh pembelajaran berbasis internet.

Pembelajaran talaqqi dan musyafahah memang tidaklah menjadi metode pembelajaran populer seperti pembelajaran modern berbasis internet seperti saatini, akan tetapi kekurangan pembelajaran berbasis internet pada pembelajaran Al-Qur'an membuat guru-guru merasa perlu untuk kembali pada metode pembelajaran yang kuno tersebut. Dipastikan dengan kembali kepada metode tersebut membuat hasil dan tujuan pembelajaran yang direncanakan lebih mudah dan tepat untuk dicapai. 
Kondisi yang telah disebutkan di atas sebenarnya merupakan kondisi nyata yang dihadapi di SD Swasta Salsa, guruguru yang mengajar tabsin Qur'an mulai menyadari kelemahan dari metode-metode pembelajaran modern (berbasis internet) yang masif diterapkan pada saat ini. Bahkan di SD Swasta Salsa juga kerap menggunakan pembelajaran berbasis internet pada pelajaran-pelajaran lain selain Al-Qur'an. Jika kondisi ini terus menerus dibiarkan maka tidak menutup kemungkinan pembelajaran Al-Qur'an juga akan kehilangan rub-nya, yakni pembelajaran tajwid yang dipandu oleh seorang guru sebagaimana tradisi yang telah terjadi semenjak masa Rasulullah Saw. sampai dengan generasi saat ini.

Penelitian tentang metode talaqqi dan musyafahah memang bukanlah terbilang penelitian baru, penelitian tentang talaqqi dan musyafahah pernal dilakukan sebelumnya seperti penelitian efektivitas metode talaqqi untuk meningkatkan kemampuan menghafal Al-Qur'an anak usia dini (Susianti, 2017), peningkatan prestasi hafalan Al-Qur'an melalui metode talaqqi (Qawi, 2017), manajemen pembelajaran tahfidz. Qur'an melalui metode talaqqi (Kartika, 2019), analisis pengelolaan pembelajaran tabsin dan tahfidz menggunakan dengan metode talaqqi (Nurkarima, 2015), peningkatan kemampuan menghafal hadis dengan metode talaqqi (Novitasari, 2020), dari penelusuran tersebut dapat dikelompokkan bahwa fokus kajian terletak pada implementasinya pada pembelajaran tahfidz Qur'an pemilihan tersebut diambil karena keefektifannya dalam mengontrol hafalan Qur'an dan Hadis siswa. Penelitian ini mencoba untuk meneliti ruang kosong yang belum pernah dikaji sebelumnya yakni pada sisi keefektifannya dalam memperbaiki kualitas bacaan Al-Qur'an siswa di tengah massif dan trend pembelajaran berbasis modern menggunakan internet. Penelitian ini mencoba untuk menepis tuduhan bahwa metode pembelajaran tatap muka dan penuh control guru menjadi metode klasik dan kuno, sekaligus untuk membuktikan bahwa dalam pemilihan metode pembelajaran tidak selalu didasarkan pada modernitas dari satu metode, akan tetapi disesuaikan dengan karekteristik materi dan tujuan pembelajaran yang hendak dicapai.

Penelitian ini bertujuan untuk mengetahui kemampuan peserta didik membaca Al-Qur'an sebelum penerapan metode talaqqi dan musyafahah, kemampuan peserta didik membaca Al-Qur'an sesudah penerapan metode talaqqi dan musyafahah, Respon peserta didik terhadap metode ini dibandingkan dengan metode pembelajaran Al-Qur'an berbasis internet selama ini.

\section{KAJIAN TEORI}

Tahsin berasal dari bahasa arab "hassana-yubassinu-tabsiinan" yang berarti membaguskan, memperbaiki, menghiasi, mempercantik, membuat lebih baik dari semula. Sedangkan tajwid juga berasal dari bahasa arab "jawwada-yujawwidu-tajwiidan" yang berarti membaguskan atau menjadi bagus. Oleh karenanya kata tabsin memiliki makna yang sama dengan kata tajwid. Dalam pandangan Islam, pengertian tahsin dapat diartikan tata cara membaca Al-Qur'an dengan baik dan benar demi terjaga keaslian dalam praktik tilawah yang diajarkan melalui 
Sunnah Rasulullah sedari dulu sampai sekarang sesuai ketentuan ilmu tajwid. (R Nurkarima, 2015). Imam Jalaluddin As-Suyuthiy mendefinisikan ilmu tajwid sebagai ilmu yang memberikan huruf akan hak-haknya dan tertibnya, mengembalikan huruf kepada makhraj dan asal (sifatnya) serta menghaluskan pengucapannya dengan cara yang sempurna tanpa berlebih-lebihan, serampangan, tergesa-gesa dan dipaksakan. (Anggreini Siregar, Nihayah Husna, Nurul Huda, 2020).

Umat Islam diwajibkan untuk mempelajari ilmu tajwid, secara hukum termasuk fardhu kifayah, yang berarti suatu kewajiban yang dianggap cukup apabila disuatu tempat, wilayah atau negeri terdapat orang yang ahli dalam ilmu tajwid dan dapat bertanya kepadanya, dengan demikian kewajiban tersebut terpenuhi. (Indriyani et al., 2015). Mengenai tujuan mempelajari ilmu tahsin atau tajwid yang dinyatakan oleh Syekh Muhammad Al-Mahmud yakni supaya dapat membaca ayat-ayat Al-Qur'an dengan fashih sesuai yang diajarkan oleh Nabi Saw. dan juga supaya dapat memelihara lisan dari kesalahan-kesalahan sewaktu membaca kitab-kitab Allah Swt. yakni Alquran. Singkatnya, memberikan tuntunan atau cara-cara pengucapan ayat Al-Qur'an dengan tepat, sehingga lafal dan maknanya terpelihara.

Secara umum, pokok-pokok bahasan ilmu tajwid atau tahsin Qur'an berkaitan dengan lafaz-lafaz Al-Qur'an. Oleh karenanya ilmu ini berkaitan erat dengan materi yang berhubungan mengenai Al-Qur'an itu sendiri. Pembelajaran ilmu tajwid dengan baik dan benar merupakan bagian yang penting bagi peserta didik untuk dapat membaca Al-Qur'an. Dengan kata lain, memahami ilmu tajwid dengan baik seharusnya merupakan materi atau masuk dalam ruang lingkup mempelajari Al-Qur'an (Rahmani, 2017). Setelah peserta didik dibekali dengan ilmu tajwid, tentu peserta didik akan dapat meminimalisir kesalahankesalahan dalam membaca Al-Qur'an (Alfianto, 2017).

Mengajarkan tajwid membutuhkan metode yang tidak hanya berbasis kepada pembelajaran yang riang dan menyenangkan akan tetapi yang terpenting ialah keefektifanyna dalam mencapai keberhasilan pembelajaran. Di antara metode tersebut (fokus penelitian) ialah metode talaqqi dan Musyafahah. Metode talaqqi menurut bahasa sebagaimana yang diutarakan Ahsin memiliki arti bertemu langsung (Salma Nadhifa AsySyahida, 2020) yakni belajar secara langsung dihadapan guru sedangkan musyafahah juga memiliki arti mulut ke mulut atau bibir ke bibir. Mengenai pengertian menurut bahasa, kata talaqqi berasal dari kosa kata "laqia" yang artinya berjumpa. Makna berjumpa disini adalah bertemu secara langsung antara peserta didik dan pendidik (R Nurkarima, 2015). Dalam beberapa literatur penelitian thesis disebutkan bahwa kata talaqqi berasal dari bahasa arab "talaqqa-yatalaqqa" asal dari kata kerja "laqiya-yalqa-liqaan" yang artinya juga bertemu, berhadapan, mengambil dan menerima (Mafluchah, 2016). Penggunaan metode talaqqi untuk mempelajari Al-Qur'an sebenarnya dianjurkan bahkan menjadi suatu kewajiban, karena tidak dianjurkan seseorang belajar membaca Al-Qur'an langsung sendiri dari mushaf tanpa dibimbing oleh pendidik 
(Haq, 2016). Karakteristik utama metoe talaqqi yakni belajar ilmu agama secara langsung kepada pendidik yang mempunyai kompetensi atau kemampuan ilmu, tsiqah, dhabit (kuat ingatannya) dan sanad keilmuan yang bersambung sampai kepada Rasulullah saw. melalui para ulama 'Aalimiin 'Aarifin (Widyasari, 2018). Metode ini memang sering dipergunakan dalam kegiatan tabfidz qur'an (Susianti, 2016) akan tetapi tidak menutup kemungkinan untuk diterapkan pada pembelajaran tajwid, bahkan survey menunjukkan bahwa metode ini yang paling banyak dan tepat digunakan untuk semua tingkatan sekolah (Rizalludin, 2019).

Langkah penerapannya bermula dari petemuan pendidik dan peserta didik dalam sebuah ruangan, kemudian peserta didik duduk dihadapan atau saling berhadapan dengan pendidiknya untuk mendengarkan bacaan Al-Qur'an dengan syarat secara bertatap muka tanpa perantara apapun. (Nurzulaikha, 2019), siswa diminta untuk membaca, dan dalam hal ini pendidik langsung memberikan koreksi, dan dalam pertemuan ini juga memungkinkan siswa untuk mendapatkan sentuhan psikologis. (Diah Utami \& Maharani, 2018)

Metode Musyafahah dapat diartikan sebagai suatu proses belajar mengajar secara berhadapan antara pendidik dan peserta didik, (Andhini, 2017). Dalam penerapan metode musyafahah ini, peserta didik menyebut dan mengikuti tata cara sebutan pendidik melalui pergerakan bibir atau mulut sesuai kaidah ilmu tajwid, sehingga peserta didik mampu menyebut atau membunyikan huruf dengan tepat, mampu membedakan bacaan yang panjang dan pendek serta menyesuaikan pelafasan hukum tajwid dengan baik dan benar. Pada kebiasaannya dalam konteks tahsin Qur'an ini biasanya pendidik melakukannya secara berulangulang sehingga peserta didik lebih terampil dalam pengucapan bacaan quran sesuai ilmu tajwid.

Metode musyafahah terbukti paling lengkap dalam mengajarkan bacaan AlQur'an yang benar, dan paling mudah diterima oleh semua kalangan (Qawi, 2017). Metode ini pada umumnya memiliki kelebihan yakni pendidik lebih leluasa mengawasi perkembangan setiap peserta didiknya secara tatap muka/langsung, melihat sejauh mana kemampuan gerakan bibir peserta didik dalam mengucapkan makhrajnya yang diajarkan oleh pendidik berhadapan secara langsung. Meskipun demikian tentunya metode ini memiliki kekurangan, salah satunya metode ini tidak dapat digunakan secara terus menerus atau secara klasikal karena kurang efektif dan harus divariasikan dengan metode tertentu. Selain itu juga sebagian peserta didik mungkin akan merasa bosan terlebih menunggu giliran pengujian latihan pengucapan huruf dikarenakan kebiasaannya dilakukan secara individu. Dalam menerapkan metode talaqqi dan musyafahah ini, peserta didik harus belajar secara Al-Qur'an secara langsung dari pendidiknya karena semuanya para guru yang mengajarkan Al-Qur'an memiliki sanad sampai kepada Rasulullah Saw.(Yusof et al., 2018).

Berdasarkan penjelasan di atas tampak bahwa secara teori metode talaqqi dan musyafahah memiliki kesamaan, namun 
perbedaannya musyafahah diartikan pertemuan atau interaksi langsung, sedangkan talaqqi lebih cenderung pada pembelajaran dan evaluasi langsung dihadapan pendidik, keduanya menjadi satu kesatuan untu diterapkan dalam penelitian tindakan kelas ini. Berdasarkan pemaparan teori di atas tampak bahwa pembelajaran dengan metode ini dapat meningkatkan kemampuan membaca Al-Qur'an siswa khususnya dalam hal tajwid, dan dianggap efektif untuk menilai perkembangan dan kemahiran membaca Al-Qur'an siswa dibanding dengan pembelajaran satu arah menggunakan internet.

\section{METODE PENELITIAN}

Penelitian ini menggunakan metode penelitian tindakan kelas (PTK) melalui tahapan dua siklus. Setiap siklus terdiri empat langkah kegiatan yakni planning (rencana), action (pelaksanaan), observation (pengamatan) dan reflection (refleksi). Secara rinci dijelaskan berikut ini:

- Planning (perencanaan) terhadap kesiapan sebelum pembelajaran dilaksanakan, dalam hal ini sang guru mempersiapkan RPP dan silabus, mempersiapkan strategi dan media pembelajaran, dan mempersiapkan rubrik penilaian hasil belajar. Kegiatan planning siklus 1 terlaksana pada pada tanggal 12 Oktober 2020, dan planning siklus ke 2 terlaksana pada tanggal 19 oktober 2020 .

- Action (pelaksanaan) pembelajaran Al-Qur'an menggunakan metode talaqqi dan musyafabah sebagaimana yang telah direncanakan dalam RPP dan Silabus. Menerapkan langkah- langkah pembelajaran sebagaimana langkah-langkah pembelajaran dengan menggunakan metode talaqqi dan musyafahah. Kegiatan pembelajaran siklus 1 terlaksana pada pada tanggal 15 Oktober 2020, dan pelaksanaan pembelajaran siklus ke 2 terlaksana pada tanggal 22 oktober 2020.

- Observation (pengamatan) terhadap ketercapaian program dan hasil pembelajaran dengan membandingkannya pada KKM yang ditetapkan. Observasi dilaksanakan saat pembelajaran berlangsung dan usai pembelajaran dilaksanakan. Pengamatan dilakukan dengan instrumen observasi yang telah disediakan.

- Reflection (refleksi) merupakan kegiatan menindaklanjuti hasil observasi yang telah dilakukan. Dalam hal ini peneliti menggali kelemahan dan kekurangan yang belum tercapai pada siklus 1 untuk kemudian menjadi landasan perbaikan pada siklus 2. Secara alur gambaran dari siklus penelitian seperti tertera pada berikut ini:

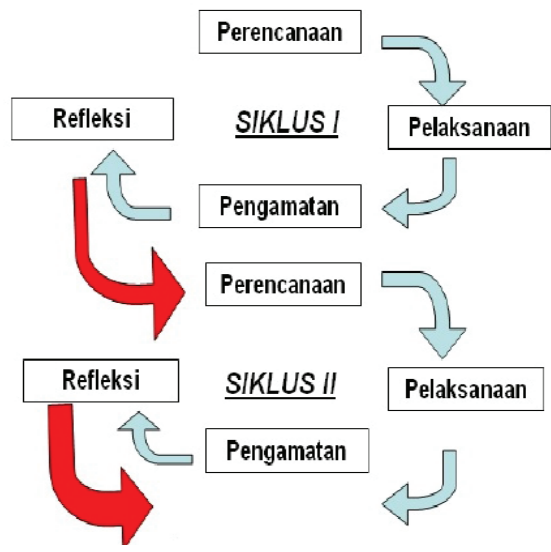

Gambar 1. Alur Penelitian Tindakan Kelas Penelitian dilaksanakan di SD Swasta Salsa yang beralamat di Jl.Siliwangi No. 1 Desa Cinta Rakyat Kec. Percut Seituan, 
Deli Serdang. Penelitian dikhususkan di kelas VI-B yang berjumlah 10 orang. Penelitian dilaksanakan dari mulai bulan oktober sampai pada bulan November 2020. Dua bulan waktu ini menujukkan waktu keseluruhan kegiatan penelitian dari mulai kegiatan observasi awal sampai pada kegiatan penulisan laporan.

Data diperloleh melalui teknik observasi, wawancara, tes, dan dokumentasi. Secara rinci kegiatan observasi dilakukan secara partisipan, yakni peneliti terlibat ikut serta dalam mengamati proses kegiatan belajar mengajar Al-Qur'an serta memperoleh data dari observasi tak struktur yaitu peneliti mengamati untaian peristiwa atau sejumlah tingkah laku belajar mengajar Al-Qur'an kemudian mencatat dan menganalisisnya. Wawancara dilakukan dengan tipe kelompok yakni pengambilan data melalui pertanyaan yang diajukan secara lisan oleh peneliti terhadap sekelompok orang dalam waktu yang bersamaan untuk mengambil data terkait pengalaman peserta didik dalam memahami ilmu tajwid dalam membaca Al-Qur'an yang terdiri dari 5 butir pertanyaan.

Tes dilakukan dengan pre test (sebelum) dan post test (sesudah) yaitu melontarkan pertanyaan kepada peserta didik untuk menguji tingkatan pengetahuan pelajaran yang akan disampaikan. Test dilakukan dengan 3 indikator yaitu ketepatan makharij al-Huruf, ketepatan shifat al-Huruf dan ketepatan pada akbkam al-Huruf. Mengenai studi dokumentasi dilakukan secara primer menyangkut subjek dan objek penelitian selama proses penelitian tindakan kelas ini berlangsung. Materi pembelajaran yang diajarkan yaitu mengenai makharil alHuruf, shifat al-Huruf dan abkeam al-Huruf.

Analisis data dilakukan melalui tahapan kegiatan meliputi menghimpun data, melakukan koding (terjun kelapangan), menampilkan data yang didapat, mereduksi beberapa data dan memverifikasi data yang terkumpul. Posisi peneliti benar-benar bereksplorasi terhadap data yang telah didapat guna sebagai salah satu komponen yang harus dipenuhi dan sebagai pengamat partisipatif memperoleh data yang relevan dalam metode penelitian tindakan kelas.

\section{HASIL DAN PEMBAHASAN PENELITIAN}

Penelitian Tindakan Kelas (PTK) mencakup prosesi implementasi metode talaqqi dan musyafahah dalam meningkatkan kemampuan membaca Al-Qur'an siswa di SD Swasta Salsa Percut Sei Tuan, penelitian dilaksanakan sebanyak dua siklus, terdiri dari empat tahapan, yaitu perencanaan, pelaksanaan, observasi dan refleksi. Setiap siklus penelitian dilaksanakan satu kali pertemuan di setiap minggunya. Alokasi waktu tiap pertemuannya 60 menit. Pembelajaran ini dikhususkan pada kelas VIB, proses pembelajaran dilakukan mulai pukul 07.30-08.30 wib. Berhubungan dengan situasi pandemi saat ini, jumlah siswa pada awalnya berjumlah 20 orang, menjadi 10 orang karena di bagi menjadi dua kelas.

\section{Kemampuan Membaca Al-Qur'an Pra Siklus}

Sebelum diterapkan metode talaqqi dan metode musyafahah dilakukan analisis terhadap kemampuan membaca Al-Qur'an siswa, hal ini dilakukan untuk menjadi 
perbandingan dalam penerapan tindakan kelas. Pengamatan dilakukan terhadap dua hal yakni respon siswa terhadap pembelajaran selama ini dan juga kemampuan membaca Al-Qur'an siswa.

Hasil wawancara dengan siswa kelas VI-B (wawancara kelompok) menunjukkan bahwa respon siswa terhadap pembelajaran Al-Qur'an berbasis online yang diterapkan selama ini belumlah maksimal dapat meningkatkan pemahaman dan ketertarikan mereka untuk belajar tajwid. Hal ini sebagaimana alasan siswa:

Belajar Al-Qur'an melalui jaringan internet, membuat kami bingung, ada banyak keterangan yang tidak kami pahami, bahkan ketika tidak paham, tidak tau harus bertanya kemana, sebab ketika ditanya di group whatsapp guru tidak dapat menjawab seluruhnya. Memang belajar dengan cara daring ini tidak membuat kita takut pada guru, tapi kalau belajar secara satu persatu kan membuat kita paham

Hasil wawancara ini menunjukkan bahwa respon siswa terhadap pembelajaran berbasis internet tidak begitu baik, hal ini ditandai dengan kurang antusiasnya mereka.

Kemudian hasil pengamatan pra siklus tentang kemampuan membaca AlQur'an siswa, dilakukan dengan megamati secara langsung penilaian rutin kemampuan belajar siswa pada bulan terakhir. Hasilnya direkapitulasikan seperti tertera di bawah ini:

Tabel 1. Rekapitulasi hasil belajar pra siklus

\begin{tabular}{|l|c|c|}
\hline \multicolumn{1}{|c|}{ Kategori } & Jumlah & $\mathbf{\%}$ \\
\hline Sangat baik (80-100) & 1 & $10 \%$ \\
\hline Baik (68-79) & 2 & $20 \%$ \\
\hline Cukup (56-67) & 5 & $50 \%$ \\
\hline Kurang baik(45-55) & 2 & $20 \%$ \\
\hline Tidak baik (0-44) & 0 & $0 \%$ \\
\hline \multicolumn{1}{|c|}{ Total } & $\mathbf{1 0}$ & $\mathbf{1 0 0} \%$ \\
\hline
\end{tabular}

Dalam bentuk grafik seperti tertera pada berikut:

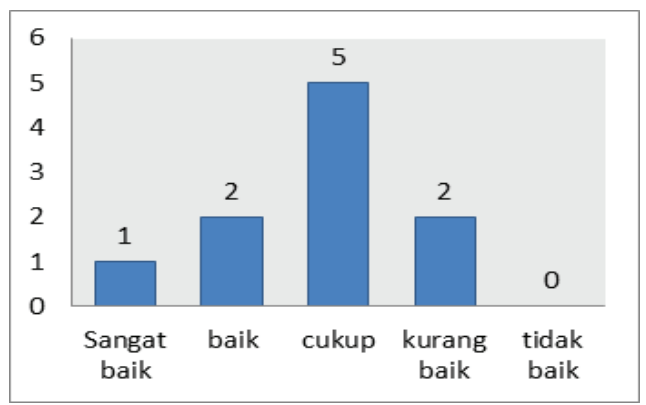

Grafik 1. Rekapitulasi hasil belajar pra siklus

Berdasarkan tabel 1. Tampak bahwa terdapat $1(10 \%)$ orang dengan kategori kemampuan membaca Al-Quran sangat baik, $2(20 \%)$ orang dengan kategori baik, dan $5(50 \%)$ orang dengan kategori cukup, dan $2(20 \%)$ orang dengan kategori kurang baik, dan tidak seorang siswa pun $(0 \%)$ dengan kategori tidak baik.

Hasil ini menunjukkan bahwa hamper $70 \%$ siswa perlu mendapatkan perbaikan khusus agar kemampuan membaca Al-Qur'an mereka menjadi sangat baik. Hal ini lah kemudian yang mendasari peneliti semakin yakin untuk menerapkan metode pembelajaran talaqqi dan musyafahah.

\section{Kemampuan Membaca Al-Qur'an pada} Siklus 1

Kegiatan pembelajaran pada siklus 1 dimulai dengan kegiatan merencanakan pembelajaran, mulai dari mempersipakan RPP, silabus pembelajaran, dan sumber serta alat pembelajaran yang berkaitan dengan pembelajaran. Pembelajaran dilakukan melalui tahapan pembelajaran sebagai berikut:

- Guru memasuki kelas dengan mengucapkan salam

- Guru memulai kegiatan pembelajaran 
dengan melakukan apersepsi, pemberian motivasi, pemaparan kompetensi, serta tujuan yang diharapkan

- Guru memberikan penjelasan terkait dengan hukum nun sukun dan tanwin yang didalamnya menyangkut tiga indikator yakni makharijul huruf, sifatul buruf, dan abkamul buruf.

- Penjelasan dengan membagai hukumhukum, menjelaskan kareteristik masing-masing hukum, dan mempraktikkan membacanya

- Kemudian meminta siswa satu persatu untuk maju menghadap guru dan melafalkan bacaan Al-Qur'an dengan menerapkan apa yang telah dijelaskan dan dicontohkan oleh guru

- Guru memberikan koreksi dan pembenaran terhadap yang telah dibacakan oleh siswa. Koreksi langsung diberikan dan dibimbing secara tahap demi tahap, sampai akhirnya siswa tersebut mampu untuk melafalkannya.

- Guru melakukan evaluasi terhadap setiap siswa, dengan memberika penilaian pada rubrik penilaian keterampilan. Penilaian dilakukan dengan mengukur ketercapaian indikator pembelajaran.

- Guru memberikan kesimpulan dan menutup pembelajaran.

Adapun jabaran hasil penilaian pembelajaran kemampuan membaca Alqur'an setelah penerapan metode talaqqi dan musyafahah pada siklus 1 dilakukan menggunakan rubrik penilaian keterampilan menggunakan skala sangat baik, baik, cukup, kurang baik, dan tidak baik. Adapun hasilnya seperti yang dijabarkan pada tabel dan grafik di bawah ini:

Tabel 2. Rekapitulasi hasil belajar siklus 1

\begin{tabular}{|c|c|c|c|}
\hline \multirow{2}{*}{ Kategori } & \multicolumn{3}{|c|}{ Indikator } \\
\cline { 2 - 4 } & MH & SH & AH \\
\hline $\begin{array}{c}\text { Sangat baik } \\
(80-100)\end{array}$ & 2 & 1 & 2 \\
\hline $\begin{array}{c}\text { Baik } \\
(68-79)\end{array}$ & 3 & 4 & 5 \\
\hline $\begin{array}{c}\text { Cukup } \\
(56-67)\end{array}$ & 5 & 5 & 3 \\
\hline $\begin{array}{c}\text { Kurang baik } \\
(45-55)\end{array}$ & 0 & 0 & 0 \\
\hline $\begin{array}{c}\text { Tidak baik } \\
(0-44)\end{array}$ & 0 & 0 & 0 \\
\hline Jumlah & 10 & 10 & 10 \\
\hline
\end{tabular}

Keterangan:

$$
\begin{aligned}
\mathrm{MH} & =\text { Makbarijul Huruf } \\
\mathrm{SH} & =\text { Sifatul Huruf } \\
\mathrm{AH} & =\text { Abkamul Huruf }
\end{aligned}
$$

Uraian tabel di atas jika digambarkan pada grafik tampak seperti di bawah ini:

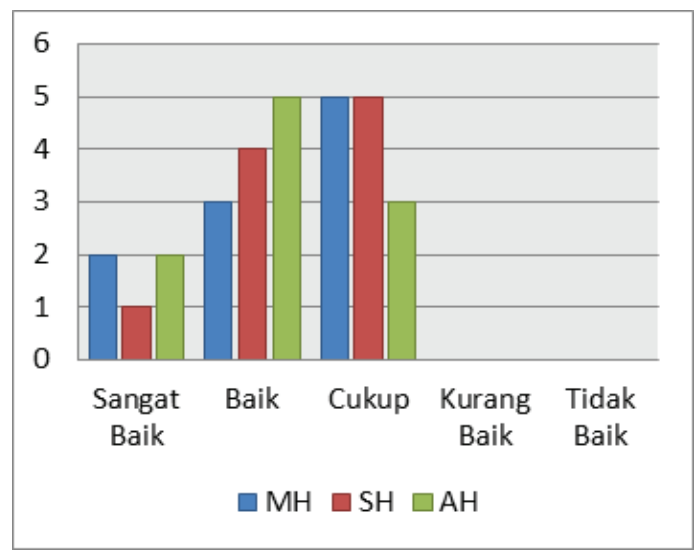

Grafik 2. Rekapitulasi hasil belajar siklus 1

Berdasarkan data pada tabel dan grafik di atas dapat dideskripsikan bahwa perolehan nilai untuk indikator makaharijul buruf pada kategori sangat baik sebanyak 2 orang, baik terdapat 3 orang, cukup terdapat 5 orang, dan tidak terdapat satu orang pun 
yang pada kategori kurang baik dan tidak baik. Untuk indikator sifatul buruf pada kategori sangat baik sebanyak 1 orang, kateogri baik 4 orang, kategori cukup 5 orang, dan tidak terdapat siswa yang berada pada kategori kurang baik dan tidak baik. Untuk indikator abkamul huruf pada kategori sangat baik terdapat 2 orang, kategori baik terdapat 5 orang, kategori cukup 3 orang dan tidak terdapat siswa pada kategori kurang baik dan tidak baik.

Hasil observasi terhadap kegiatan pada siklus 1 terdapat beberapa kelemahan sehingga masih terdapat siswa yang masih berada pada kategori cukup, dan kategori ini belum dapat dikategorikan memenuhi kriteria ketuntasan minimal yakni 80 .

Berdasarkan pengamatan ditemukan beberapa permasalahan yang menghambat tercapainya tujuan pembelajaran tersebut yakni kurangnya alokasi waktu pembelajaran, kurangnya kemauan siswa untuk menjelaskan kekurangannya, dan sulitnya memantau perkembangan pemahaman siswa yang tidak tuntas.

Sebagai refleksi terhadap hambatan tersebut, pada siklus 2 lebih difokuskan untuk memberikan pemahaman lebih terkait dengan sifatul buruf, dan abkamul huruf, sehingga lebih tepat dalam melafalkan bacaan sesuai kaidah tajwid yang ada.

\section{Kemampuan Membaca Al-Qur'an pada}

Siklus 2

Perencanaan pembelajaran pada siklus 2 disesuaikan berdasarkan refleksi pada siklus 1. Karena hambatan pencapaian KKM pada siklus 1 terletak pada indikator sifatul buruf, dan abkamul buruf yang menghambatnya siswa untuk melafalkan bacaan sesuai dengan makharijul huruf, maka perencanaan lebih di arahkan untuk bagaimana memberikan pengayaan terhadap dua indikator tersebut. Pada tahap ini guru menulis kembali RPP dengan kompetensi dasar yang sama seperti siklus 1 akan tetapi materi pembelajaran lebih ditekankan untuk mencapai kemampuan membaca sesuai dengan ketepatan makbarijul buruf dengan memberikan pengayaan pada sifatul buruf, dan abkamul buruf.

Pembelajaran dilakukan melalui tahapan berikut:

- Guru memasuki kelas dengan mengucapkan salam

- Guru memulai kegiatan pembelajaran dengan melakukan apersepsi, pemberian motivasi, pemaparan kompetensi, serta tujuan yang diharapkan

- Guru fokus menjelaskan tentang materi nun sukun dan tanwin akan tetapi pada sifatul buruf, dan abkamul burufnya.

- Guru meminta siswa untuk melafalkan ayat tetapi penekanannya khusus pada bagian tajwid yang belum mencapai KKM saja

- Guru memberikan pembenaran atau koreksi terhadap bacaan siswa

- Menutup kajian dengan membaca ayat Al-Qur'an bersama-sama kembali.

- Guru memberikan simpulan dan penguatan terhadap materi

Adapun hasil pembelajaran siswa terkait dengan kemampuan mereka membaca Al-Qur'an hukum nun sukun dan tanwin pada siklus 2 sebagai berikut: 
Tabel 3. Rekapitulasi hasil belajar siklus 2

\begin{tabular}{|c|c|c|c|}
\hline \multirow{2}{*}{ Kategori } & \multicolumn{3}{|c|}{ Indikator } \\
\cline { 2 - 4 } & $\mathbf{M H}$ & $\mathbf{S H}$ & $\mathbf{A H}$ \\
\hline $\begin{array}{c}\text { Sangat baik } \\
(80-100)\end{array}$ & 8 & 8 & 8 \\
\hline $\begin{array}{c}\text { Baik } \\
(68-79)\end{array}$ & 2 & 2 & 2 \\
\hline $\begin{array}{c}\text { Cukup } \\
(56-67)\end{array}$ & 0 & 0 & 0 \\
\hline $\begin{array}{c}\text { Kurang baik } \\
(45-55)\end{array}$ & 0 & 0 & 0 \\
\hline $\begin{array}{c}\text { Tidak baik } \\
(0-44)\end{array}$ & 0 & 0 & 0 \\
\hline Jumlah & 10 & 10 & 10 \\
\hline
\end{tabular}

Keterangan:

$\begin{aligned} \mathrm{MH} & =\text { Makharijul Huruf } \\ \mathrm{SH} & =\text { Sifatul Huruf } \\ \mathrm{AH} & =\text { Abkamul Huruf }\end{aligned}$

Data pada tabel berikut digambarkan dalam bentuk grafik, maka hasilnya seperti di bawah ini:

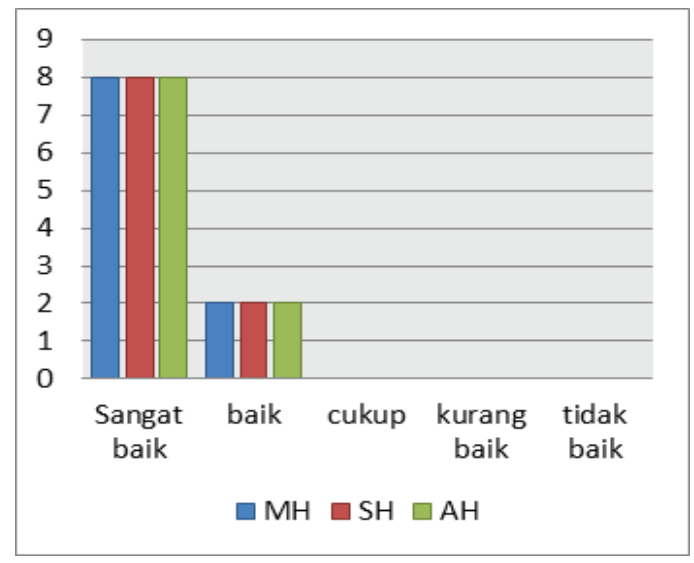

Grafik 3. Rekapitulasi hasil belajar siklus 2

Berdasarkan tabel 2 dan grafik 2 di atas dapat dideskripsikan bahwa kemampuan siswa membaca Al-Qur'an mengalami peningkatan yang signifikan, hal ini terlihat dari perolehan nilai untuk indikator makharijul huruf dengan kateogri sangat baik sebanyak 8 orang, kategori baik sebanyak 2 orang, dan tidak seorang pun siswa berada pada kategori cukup, kurang baik, dan tidak baik. Kemudian untuk indikator sifatul buruf dengan kategori sangat sebanyak 8 orang, kategori baik 2 orang, dan tidak seorang pun juga berada pada kategori cukup, kurang baik, dan tidak baik. Sedangkan untuk indikator akhamul huruf juga demikian terdapat 8 orang pada kategori baik, dan 2 orang pada kategori baik, dan tisak seorang pun siswa berada ada kategori cukup, kurang baik, dan tidak baik.

Hasil ini menujukkan peningkatan yang sigifikan antara siklus 1, dan siklus 2 . Terus mengalami peningkatan hasil belajar untuk setiap siklusnya. Perbedaan tersebut dijabarkan pada tabel seperti di bawah ini:

Tabel 4. Perbandingan hasil belajar pada siklus 1, dan siklus 2

\begin{tabular}{|l|c|c|}
\hline \multirow{2}{*}{ Indikator } & \multicolumn{2}{|c|}{ Memenuhi KKM } \\
\cline { 2 - 3 } & SIklus I & Siklus II \\
\hline MH & 2 & 8 \\
\hline SH & 1 & 8 \\
\hline AH & 2 & 8 \\
\hline
\end{tabular}

Dalam bentuk grafik asil tersebut dapat digambarkan seperti di bawah ini:

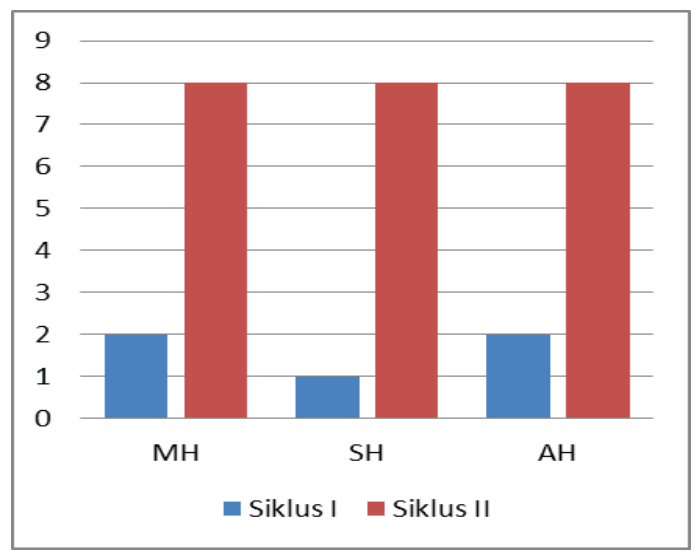

Grafik 4. Perbandingan hasil belajar pada siklus 1 dan siklus 2

Keterangan:

$$
\begin{aligned}
\mathrm{MH} & =\text { Makharijul Huruf } \\
\mathrm{SH} & =\text { Sifatul Huruf } \\
\mathrm{AH} & =\text { Abkamul Huruf }
\end{aligned}
$$


Berdasarkan tabel 4 dan grafik 4 di atas dapat dideskripsikan bahwa metode talaqqi dan musyafahah dapat meningkatkan kemampuan membaca Al-Qur'an siswa. Hal ini terbukti dari perolehan hasil belajar siswa yang meningkat dari siklus 1 sampai pada siklus 2. Pada siklus 1 untuk indikator makharijul buruf hanya terdapat 2 siswa saja yang memenuhi KKM, pada siklus 2 meningkat menjadi 8 siswa. Untuk indikator sifatul huruf pada siklus 1 hanya terdapat 1 siswa saja yang memenuhi KKM, pada siklus 2 meningkat menjadi 8 orang. Untuk indikator abkamul buruf terdapat pada siklus 1 hanya terdapat orang yang memenuhi KKM, pada siklus 2 meningkat menjadi 8 orang. Hasil ini menunjukkan bahwa metode talaqqi dan musyafahah dalam pembelajaran tajwid lebih dapat meningkatkan kemampuan membaca Al-Qur'an siswa di bandingkan dengan pembelajaran berbasis internet.

\section{Respon Siswa terhadap tindakan pembelajaran}

Ketika penerapan metode talaqqi dan musyafabah dalam pembelajaran tahsin AlQur'an memang ditemui beberapa kendala, akan tetapi secara umum respon siswa sangat antusias dan menunjukkan ketertarikan dengan penerapannya. Hal ini berdasarkan wawancara yang penulis lakukan kepada siswa secara berkelompok, yakni:

"kami sangat suka belajar dengan ustadz, sebab kalau belajarnya berhadap-hadapan seperti ini kami jadi lebih cepat mengerti, bahkan kalaupun ada yang kami tidak tahu, kami bias langsung tanyakan kepada ustadz. Kami juga senang sebab pembelajaran ini membuat kami merasa nyaman dalam belajar sebab ustadnya tidak marah, akan tetapi mau mengajari kami secara perlahanlahan sampai kami mengerti. Malah kami berharap kalau belajar Al-Qur'an selalu seperti ini”.

Belajar melalui internet memang menarik perhatian siswa, sebab visualisasi yang ditampilkan memang menimbulkan ketertarikan siswa dan menimbulkan minat belajar. Akan tetapi pembelajaran seperti ini menurut mereka tidak dapat memberikan pemahaman yang efektif. Banyak dari siswa yang belajar dari internet merasa kebingungan, dan bahkan tidak mengetahui sudah sejauh mana kemampuan mereka. Akhirnya mereka yang tidak dapat mencapai hasil belajar sesuai dengan KKM

Pada pembelajaran memang suasana kelas terlihat tertib, dan jauh dari riuh dan kebisingan. Berbeda dengan metode pembelajaran yang mungkin selama ini diterapkan dalam mata pelajaran lain yang lebih cenderung menfokuskan pada bagaimana siswa merasa senang dan tidak merasa terbebani dalam mengikuti pembelajaran. Pembelajaran talaqqi dan musyafahah memang jauh dari kesenangan bahkan terlihat kondisi yang serius dalam pembelajaran. Akan tetapi sesungguhnya kondisi ini tercipta karena sikap akhlak yang dimiliki oleh siswa saat bertemu dan berhadapan dengan pendidik langsung, sehingga rasa segan dan nervous mewarnai sikap yang muncul pada diri siswa, akan tetapi sebagaimana yang telah disebutkan sebelumnya bahwa konsentrasi dari pencapaian strategi ini pada kemampuan dalam menerapkan apa yang telah dicontohkan oleh gurunya, dan hal itu memungkinkan jika dilakukan sedekat mungkin dengan gurunya. 


\section{SIMPULAN}

Berdasarkan hasil dan pembahasan penelitian di atas dapat disimpulkan bahwa kemampuan siswa dalam membaca AlQur'an pada pra siklus belum memenuhi kriteria ketuntasan minimal yang telah ditetapkan, terbukti dari perolehan nilai yang hanya 1 siswa saja yang mampu untuk mencapai KKM. Setelah penerapan metode talaqqi dan musyafabab (siklus 1) peningkatan kemampuan membaca Al-Qur'an siswa meningkat menjadi indikator makharijul huruf terdapat 2 siswa yang memenuhi KKM, pada siklus 2 meningkat menjadi 8 siswa. Untuk indikator sifatul buruf pada siklus 1 terdapat 1 siswa yang memenuhi KKM, pada siklus 2 meningkat menjadi 8 orang. Untuk indikator abkamul huruf terdapat pada siklus 1 hanya terdapat orang yang memenuhi KKM, pada siklus 2 meningkat menjadi 8 orang. Respon siswa dalam pembelajaran dengan metode talaqqi dan musyafahah sangat positif, pembelajaran terlihat dengan suasana kondusif, dan siswa merasakan pemahaman yang lebih cepat dan tepat dibandingkan dengan metode yang diterapkan sebelumnya.

\section{DAFTAR PUSTAKA}

Alfianto, E. (2017). Penerapan Ilmu Tajwid Dalam Pembelajaran Al-Qur'an Untuk Mengembangkan Kemampuan Membaca Alquran Pada Siswa Kelas Atas SD Mubammadiyah 14 Surakarta [Skripsi: Universitas Muhammadiyah Surakarta]. http:/ / eprints.ums.ac.id/51213/

Andhini, N. F. (2017). Peran Guru dalam Pembelajaran Muatan Lokal Musyafahah dan Tajwid. Journal of Chemical Information and Modeling, 53(9), 1689-1699.
Anggreini Siregar, Nihayah Husna, Nurul Huda, T. S. (2020). Program Pengenalan Ilmu Tajwid Melaui Media Pembelajaran Pohon Ilmu. Maslahah: Jurnal Pengabdian Masyarakat, 1(2), 85-95. https://doi.org/10.30596/ maslahah.v

Diah Utami, R., \& Maharani, Y. (2018). Kelebihan dan Kelemahan Metode Talaqqi dalam Program Tahfidz AlQur'an Juz 29 dan 30 Pada Siswa Kelas Atas Madrasah Ibtidaiyah Muhammadiyah. Profesi Pendidikan Dasar, 1(2), 185. https://doi. org/10.23917/ppd.v1i2.7353

Hadisi, L., \& Muna, W. (2015). Pengelolaan Teknologi Informasi dalam Menciptakan Model Inovasi Pembelajaran (E-Learning). al-Ta'dib: Jurnal Kajian Ilmu Kependidikan, 8(1), 117-140. http://dx.doi.org/10.31332/ atdb.v8i1.396

Haq, A. M. I. (2016). Peer Mentoring Membaca Al-Qur'an Intensif Melalui Metode Talaqqi. Utile Jurnal Kependidikan, 2(2), 150-155. https:// doi.org/https://doi.org/10.37150/jut. v2i2.283

Indriyani, F., Studi, P., \& Akuntansi, K. (2015). Rancangan Pembelajaran Ilmu Tajwid Berbasis Multi Media Untuk Siswa Tingkat Dasar Pada Taman Pendidikan Al-Qur'an DTA At-Taqwa. Paradigma, 17(2), 44-49.

Kartika, T. (2019). Manajemen Pembelajaran Tahfidz Al-Qur'an Berbasis Metode Talaqqi. Jurnal Isema: Islamic Educational Management, 4(2), 245-256. https:/ / doi. org/10.15575/isema.v4i2.5988

Lubis, R. R., Hanafiah, M. A., Sartika, D., Hasibuan, A. A., \& Nawawi, K. H. (2019). Tahfidz Online; (Studi Menghafal Al-Quran Pada Masa 
Pandemi Covid-19 di MIS Ubudiyah Medan). Jurnal Pendidikan Islam, 9(2), 60-75. https://doi.org/10.38073/jpi. v9i2.253

Lubis, R. R., Mahrani, N., Margolang, D., \& Assingkily, M. S. (2020). Pembelajaran Al-Qur'an Era Covid-19: Tinjauan Metode dan Tujuannya pada Masyarakat di Kutacane Aceh Tenggara. KUTTAB, $4(2)$.

Mafluchah, S. (2016). Efektivitas Metode Talaqqi \& Musyafahah dalam Pembelajaran Tahfirh Al-Qur'an (Studi Kualitatif Mabasiswi Institut Ilmu Al-Qur'an (IIQ) Jakarta). Institut Ilmu Al-qur'an (IIQ) Jakarta.

Novitasari, D. (2020). Peningkatan kemampuan Menghafal Hadits Tentang Takwa Mata Pelajaran Al-Qur'an Hadits Melalui Metode Talaqqipada Siswa kelas IV-BMI Islamiyah Sumberwudi Karanggeneng Lamongan [UIN Sunan Ampel Surabaya]. http://digilib. uinsby.ac.id/42782/

Nurkarima, R. (2015). Analisis Pengelolaan Pembelajaran Tahsin dan Tabfidz. AlQur'an dengan Metode Talaqqi Kelas VIII di SMPIT Qordova Rancaekek [Fakultas Tarbiyah Universitas islam Bandung (UNISBA)]. http://repository.unisba. ac.id:8080/handle/123456789/5196

Nurzulaikha,N.(2019).Efektivitas Penerapan Metode Talaqqi untuk Membentuk Kemampuan Menghafal Surat-surat Pendek Santri Taman Pendidikan AlQur'an Nurul Falah Manyampa Desa Bontoala Kec. Pallangga Kab. Gowa. In Nanotechnology (Vol. 27, Issue 9). UIN Alauiddin Makassar.

Putra, A. S., \& Radita, F. R. (2020). Paradigma Belajar Mengaji Secara Online pada Masa Pandemic Coronavirus Disease 2019 (Covid-19). Mataazir: Jurnal Administrasi Dan Manajemen Pendidikan,
1(1), 49-61. http://jurnal.stainmadina.ac.id/index.php/mata/article/ view/41

Qawi, A. (2017). Peningkatan Prestasi Belajar Hafalan Al-qur'an Melalui Metode Talaqqi di MTSN Gampong Teungoh Aceh Utara. Jurnal Ilmiah: Islam Futura, 16(2), 265-283. http:// dx.doi.org/10.22373/jiif.v16i2.1327

R Nurkarima. (2015). Landasan Teoritis Tentang Pengelolaan Pembelajaran Tabsin dan Tabfidr. Al-Qur'an dengan Metode Talaqqi. Universitas Islam Bandung.

Rahmani, D. P. (2017). Implementasi Pembelajaran Tajwid dan Keterampilan Membaca Al-qur'an dalam Materi Alqur'an Hadits Pada Siswa Kelas VII Di MTs. Al-Manar Bener Tengaran Tabun Ajaran 2016/2017. Institut Agama Islam Negeri Salatiga.

Rizalludin, A. (2019). Implementasi Metode Talaqqi dalam Pembelajaran Tahsin dan Tahfiz Al-Qur'an. Khazanah Pendidikan Islam, 1(1), 22-37. https:// doi.org/10.15575/kp.v1i1.7138

Rusadi, B. E., Widiyanto, R., \& Lubis, R. R. (2019). Analisis Learning And Inovation Skills Mahasiswa PAI Melalui Pendekatan Saintifik dalam Implementasi Keterampilan Abad 21. Conciencia, XIX(2), 112-131. https://doi.org/10.19109/conciencia. v19i2.4323

Salma Nadhifa Asy-Syahida, A. M. R. (2020). Studi Komparasi Metode Talaqqi dan Metode Tilawati dalam Meningkatkan Kemampuan Membaca Al-Qur'an. Jurnal Pendidikan Islam Indonesia, 4(2), 186-191. https://doi.org/10.35316/ jpii.v4i1.166

Sopianudin, I. (2018). Aplikasi Pembelajaran Ilmu Tajwid Berbasis Android (Studi Kasus di Madrasah Tsanawiyah Darussalam- 
Cikarang) [Universitas Komputer Indonesia]. https://repository.unikom. ac.id/58972/

Susianti, C. (2016). Efektivitas Metode Talaqqi dalam Meningkatkan Kemampuan Menghafal Al-Qur'an Anak Usia Dini. Tunas Siliwangi, 2(1), $1-19$.

Susianti, C. (2017). Efektivitas Metode Talaqqi dalam Meningkatkan Kemampuan Menghafal Al-Qur'an Anak Usia Dini. Tunas Siliwangi: Jurnal Program Studi Pendidikan Guru PAUD STKIP Siliwangi Bandung, 2(1), 1-19.

Widyasari, R. (2018). Pembelajaran Tahfizul Quran Dengan Metode Talaqqi Pada Santri Kelas I'dadi di Kuttab Tahfizul Quran Al-Husnayain Surakarta Tahun Pelajaran 2018/2019. In Sifonoforos (Issue August 2015). IAIN Surakarta.

Yusof, N. H. bin, Razali, M. A. bin M., Omar, N. binti, Abdelgelil, M. F. M., \& Hamzah, M. S. bin. (2018). Concept and Execution of Talaqqi and Musyafahah Method in Learning Al-Quran. International Journal of Academic Research in Business and Social Sciences, 8(11), 559565. https://doi.org/10.6007/ijarbss/ v8-i11/4930 